\title{
O nowym ustroju szkolnictwa zawodowego w wybranych czasopismach pedagogicznych z lat 1945-1951
}

Pierwsze artykuły na temat przyszłego ustroju szkolnictwa zawodowego zaczęły się pojawiać w czasopismach pedagogicznych i prasie codziennej bardzo wcześnie, bo już w 1945 r. Powodem ich publikowania stały się rządowe propozycje zmian w kwestii oświaty polskiej, w tym także organizacji szkolnictwa zawodowego i jego programów nauczania. Do zaprezentowania wspomnianych propozycji szerszej opinii publicznej i środowisku nauczycielskiemu doszło na ogólnopolskich zjazdach i poprzedzających je zebraniach oraz konferencjach. W dniach 18-22 czerwca 1945 r. odbył się Ogólnopolski Zjazd Oświatowy w Łodzi ${ }^{1}$. Pomiędzy 15 a 18 października 1945 r. zorganizowano Zjazd Oświaty Zawodowej, a w grudniu Zjazd Delegatów Związku Nauczycielstwa Polskiego w Bytomiu. Przygotowane przez Ministerstwo Oświaty projekty reform szkolnych były w zasadzie pochodną poglądów głoszonych przez PPR. Nauka na poziome podstawowym miała trwać o jeden rok dłużej i uwzględniać w równym wymiarze kształcenie humanistyczne, matematyczno-przyrodnicze i artystyczne. Szkoła

* Dr, Katedra Historii Oświaty i Wychowania, Wydział Pedagogiczny, Uniwersytet Pedagogiczny im. KEN w Krakowie, 30-060 Kraków, ul. Ingardena 4.

1 Na temat reformy szkolnictwa i Zjazdu Oświatowego w Łodzi w 1945 r. w prasie pedagogicznej i codziennej ukazało się blisko sześćdziesiąt różnego rodzaju artykułów. Najciekawsze to: W. B i e ń k o w s k i, O nowy ustrój szkolny, „Nowa Szkoła” [dalej: NS] 1945, nr 1-2; t e n ż e, Realizujemy demokratyczną szkołe wszystkich stopni, „Życie Warszawy” 1945, nr 146; H. D o b r o w o I s k i, O nowy kierunek w nauczaniu historii, „Dziennik Polski” 1945, nr 3; T. W o j e ń s k i, Światopoglądowe podstawy jędrzejewiczowskiej reformy programów szkolnych, NS 1945, nr 1-2; B. W ó j c i e, O reformę ustroju szkolnego, „Rzeczypospolita” 1945, nr 170. 
zawodowa miała ulec daleko idącej przemianie tak, aby w szerszym zakresie stała się dostępna dla młodzieży robotniczej i chłopskiej. Jeden z ważniejszych referatów programowych z tego okresu, który zaprezentowano na Zjeździe Oświaty Zawodowej, poświęcony został Drogom realizacji kształcenia zawodowego w Polsce. Przyjęto w nim, że nowy kierunek rozwoju szkoły zawodowej powinien przebiegać od wąsko pojmowanej szkoły dawnej do obecnej pełnowartościowej szkoły obejmującej zarówno kształcenie ogólne, jak i zawodowe ${ }^{2}$. W opozycji do propozycji Ministerstwa Oświaty, kierowanego przez S. Skrzeszewskiego, pozostawał Związek Nauczycielstwa Polskiego, który stał się w tym czasie drugim ważnym miejscem opiniotwórczym. Przeważali w nim wówczas działacze związani z rządem polskim przebywającym na emigracji. W sprawach przebudowy szkolnictwa Związek wypracował własne stanowisko, nieco inne niż zaproponowało Ministerstwo Oświaty, oparte na założeniu, że tak duże przedsięwzięcie jak reforma szkolnictwa wymaga planowych i długofalowych działań. Powinny one obejmować odbudowę i reorganizację sieci szkolnej oraz powolne przejście do nowych programów nauczania. Za niezbędne uznano odpowiednie przygotowanie kadry nauczycielskiej i zaopatrzenie szkół w środki materialne oraz rozszerzenie społecznej podstawy działalności szkoły i pracy nauczycielskiej. ZNP wysunął propozycję powołania do życia powszechnego systemu kształcenia zawodowego, który przede wszystkim dopuszczałby państwową kontrolę i opiekę wychowawczą w zakładach wytwórczych. Postulował powołanie zakładów szkoleniowo-wytwórczych, umożliwiających nauczanie w niektórych działach i objęcie całej młodzieży kształcącej się praktycznie obowiązkowym dokształcaniem. Dla najzdolniejszych uczniów proponowano dalsze kształcenie w szkołach wyższych ${ }^{3}$.

Związek nauczycielski zaprezentował też własne stanowisko w sprawach wychowania młodzieży, o których publicznie mówił Czesław Wycech i Kazimierz Maj. Nakreślone przez C. Wycecha cele wychowania miały odpowiadać nowemu ustrojowi - demokracji społecznej. Wychowanie w tym ustroju powinno dokonać się w ścisłym powiązaniu z życiem państwa, jego potrzebami społeczno-gospodarczymi i politycznymi. Istotnym elementem tego całego procesu miała być aktywność jednostki, będącej ważną częścią środowiska społecznego ${ }^{4}$. Poglądy te rozwinął następnie w "Głosie Nauczycielskim” K. Maj, jeden z czołowych działaczy ZNP. Podstawą wychowania społeczno-moralnego przyjętego przez środowisko związkowe nauczycieli stać się miały fundamentalne zasady wolności, równości, braterstwa i sprawiedliwości. Wychowanie umysłowe powinno przebiegać w duchu niczym nieograniczonej wolności naukowej i w zgodzie z własnym sumieniem. Postępowanie takie określono mianem „wychowania przez demokrację dla demokracji”’.

${ }^{2}$ B. Pot y rała, Przemiany w oświacie w Polsce w latach 1944-1948, Wrocław 1991, s. 43-48.

${ }^{3}$ K. Maj, Nasze stanowisko w sprawie reformy szkolnej, [w:] Ogólnopolski Zjazd Oświatowy w Łodzi 18-22 czerwca 1945, Warszawa 1945, s. 96-110.

${ }^{4} \mathrm{C}$. Wycech, Podstawowe zagadnienia pracy społeczno-wychowawczej szkół, Warszawa 1946, s. 47.

${ }^{5}$ K. M a j, O reformie wychowania w Polsce, „Głos Nauczycielski” 1946, nr 4, s. 49-51. 
W czasopismach pedagogicznych wychodzących w latach 1945-1951 ukazało się wiele publikacji omawiających propozycje zmian ustrojowych w szkolnictwie i sprawę demokratyzacji całego systemu oświatowego. W 1945 r. wznowiono wydawanie wielu przedwojennych czasopism, m.in.: „Chowanny” - miesięcznika Instytutu Pedagogicznego w Katowicach oraz „Głosu Nauczycielskiego”, „Pracy Szkolnej” i „Szkoły Zawodowej” - miesięczników wydawanych przez ZNP. Zaczęły też ukazywać się nowe, chociażby miesięcznik społeczno-pedagogiczny „Nowa Szkoła”, wydawany przez Ministerstwo Oświaty. Powstał on z połączenia rowidowskiego „Ruchu Pedagogicznego” i „Nowej Szkoły” - miesięcznika Ministerstwa Oświaty, redagowanego przez Teofila Wojeńskiego. Pojawiło się kilkanaście lokalnych tytułów: „Miesięcznik Pedagogiczny” - wydawnictwo Oddziału Grodzkiego ZNP w Łodzi, „Okólnik Wydziału Pedagogicznego Zarządu Okręgu Pomorskiego ZNP w Toruniu” czy „Demokracja i Wychowanie” - dwumiesięcznik Instytutu Pedagogicznego w Katowicach, który miał zastąpić przedwojenną „Chowannę”7.

Nie do końca rozstrzygnięte kwestie zmian ustrojowych w polskim szkolnictwie zawodowym w omawianym okresie sprawiły, że prasa pedagogiczna stała się wygodnym miejscem do prezentowania własnych poglądów. Wypowiedzi na ten temat zamieszczane były dość często w miesięcznikach „Szkoła Zawodowa” i „Nowa Szkoła”, dwumiesięczniku „Głos Nauczycielski” czy rzadziej w kwartalniku „Ruch Pedagogiczny”. Pierwsze z wymienionych czasopism było najbardziej odpowiednie do prezentowania rozwiązań ustrojowych w szkolnictwie zawodowym, ponieważ właściwie w całości zajmowało się problematyką związaną z tym szkolnictwem. Poruszano w nim kwestie istotne dla całego systemu kształcenia i edukacji zawodowej. Początkowo wydawane numery rozpoczynały się od propagowania ważnych wydarzeń z życia politycznego lub gospodarczego, następnie dopiero przechodzono do problematyki związanej ze szkolnictwem zawodowym. Bardzo wysoko należy ocenić jeden z działów w tym czasopiśmie, zatytułowany „Z życia szkół zawodowych w Polsce”. Możemy go dzisiaj uznać za wartościowe źródło do badań nad dziejami edukacji i szkolnictwa zawodowego pod warunkiem krytycznego spojrzenia na te niezwykle złożone czasy. „Nowa Szkoła” i „Głos Nauczycielski” były czasopismami pedagogicznymi o bardziej ogólnym charakterze, w których szerzej dyskutowano o problemach edukacji, szkolnictwie i współczesnej pedagogice. „Ruch Pedagogiczny” starał się pretendować do miana czasopisma naukowego.

Na szczególną uwagę w wychodzącej od 1945 r. „Szkole Zawodowej” zasługuje artykuł Władysława Bieńkowskiego, który proponuje równe traktowanie szkoły zawodowej i ogólnokształcącej. Jednym z elementów tego równego traktowania miało być umożliwienie absolwentom szkół zawodowych wstępu na niektóre wydziały szkół wyższych. Wymagałoby to gruntownej rewizji programów nauczania tych szkół pod kontem zbliżenia ich do programów szkół ogólnokształcących. Bieńkowski był przeciwny, aby warsztatom rzemieślniczym i fabrykom

${ }^{6}$ W związku z dużym zapotrzebowaniem społecznym na to czasopismo od 1946 r. „Głos Nauczycielski" stał się dwutygodnikiem i przyjął postać gazety.

7 Czasopisma pedagogiczne w Polsce Ludowej, red. F. Filipowicz, Warszawa 1981, s. 49-50. 
odebrano możliwość prowadzenia szkoleń uczniów w zakresie zręczności posługiwania się podstawowymi narzędziami i maszynami. W tym względzie proponował rozwiązania funkcjonujące w szkolnictwie amerykańskim, które nie tylko zapewniało kontakt z narzędziami i warsztatem, lecz także kładło duży nacisk na zdobycie wiedzy teoretycznej.

Bardzo szybko, bo już w lipcu 1945 r., w numerze drugim „Głosu Nauczycielskiego" pojawiło się jednoznaczne stanowisko ZNP w sprawie przyszłego ustroju szkolnictwa zawodowego. Zostało wyrażone w artykule Jana Baculewicza zatytułowanym Problemy ustroju i organizacji szkolnictwa zawodowego. Zawarte w nim propozycje były próbą odniesienia się do zignorowanych przez Ministerstwo Oświaty uwag, zgłoszonych przez Sekcję Szkolnictwa Zawodowego ZNP i Wydział Pedagogiczny Komisji Reformy Ustroju Szkolnego ZNP. W opinii Sekcji i Komisji, poza wszelką dyskusją pozostawały jedynie te rozwiązania, które będą zmierzać do upowszechnienia kształcenia zawodowego uzasadnionego potrzebami gospodarczymi oraz koniecznością zniweczenia strat wojennych. W ocenie tych dwóch ciał związkowych, ustrój szkolnictwa zawodowego powinien opierać się na ośmioklasowej szkole powszechnej. Do jego zadań należało przygotowanie młodzieży pod względem praktycznym i teoretycznym do pracy w wybranym zwodzie, ponadto wykształcenie ogólne miało umożliwiać naukę w szkołach wyższych. W zakresie gęstości sieci szkolnej szkoły zawodowe miały być dostosowane do potrzeb ilościowych przemysłu, rzemiosła, administracji i życia społecznego. Jego schemat organizacyjny obejmował:

- szkoły zawodowe typu zasadniczego o dwóch szczeblach programowych w zakresie kształcenia zawodowego;

- szkoły fabryczne, będące pośrednią formą między szkołami typu zasadniczego i szkołami dokształcającymi;

- szkoły obowiązkowe (dokształcające), łączące pracę w zwodzie z nauką w szkole.

Przyjęty system powinien być niezwykle elastyczny. Niezależnie od wymienionych sposobów kształcenia zawodowego mógłby uwzględniać także inne drogi, np. kursy specjalne, technika, politechniki robotnicze, które byłyby zróżnicowane pod względem czasu trwania nauki i poziomu kształcenia. Poważnie rozmyślano o upowszechnieniu wychowania gospodarczego, które powinno rozpoczynać się jak najwcześniej, bo już w szkole powszechnej i innych szkołach ogólnokształcących?

W „Nowej Szkole” w 1945 r. ukazał się bardzo odważny artykuł Stanisława Godeckiego Szkolnictwo spółdzielcze, w którym autor żądał wręcz rehabilitacji spółdzielczego szkolnictwa zawodowego. Absolwentom tych szkół, na zasadach preferencyjnych, chciał umożliwić wstęp do niektórych szkół wyższych. Możli-

${ }^{8}$ Uwagi przedstawione przez J. Baculewicza były odpowiedzą na propozycje Ministerstwo Oświaty w sprawie ustroju szkolnictwa zawodowego zaprezentowane podczas obrad Sekcji Szkolnictwa Zawodowego w dniach 17-19 maja 1945 r. oraz Wydziału Pedagogicznego Komisji Reformy Ustroju Szkolnego ZNP i Zjazdu Oświatowego w Łodzi.

9 J. B a c u l e w i c z, Problemy ustroju i organizacji szkolnictwa zawodowego, „Głos Nauczycielski" 1945 , nr 1-2, s. 43-47. 
wości takie otworzyłyby się za sprawą dokonania gruntownej rewizji programów nauczania w kierunku wzmocnienia przygotowania teoretycznego i ogólnego. Szkoły te nie powinny zastępować warsztatów i fabryk w opanowaniu zręczności posługiwania się narzędziami i maszynami, ponieważ te można zdobyć po kilkutygodniowym pobycie w zakładzie. Proponował wzorowanie się na szkołach w innych krajach, które nie tyko dają uczniom kontakt z narzędziami i warsztatem, lecz także gwarantują im zdobycie wszechstronnej wiedzy ${ }^{10}$. Podobny charakter miał artykuł Stanisława Godlewskiego zatytułowany W jakim kierunku powinna iść reforma szkolnictwa handlowego, w którym autor starał się dowieść, że o rozwoju szkolnictwa handlowego powinien decydować ustrój gospodarczy Polski. Powszechnie przyjęte zasady życia gospodarczego mają wyznaczać kierunki reform tego szkolnictwa, stawiającego na wykształcenie ogólne i wzajemną współpracę nauczycieli, uczniów oraz centralnych i lokalnych środowisk gospodarczych ${ }^{11}$.

W kontekście zmian ustrojowych przedmiotem szerszej dyskusji prasowej stały się sprawy wychowania. Ukazało się wiele artykułów na ten temat. Jednym z ciekawszych był tekst Józefa Pietera zatytułowany Ideał wychowawczy nowej szkoły - człowiek współczesny, który ukazał się w „Nowej Szkole” w 1945 r. Zaprezentowany w nim ideał wychowawczy nowej szkoły przeciwstawiał się tradycyjnemu wychowaniu, upatrującemu sens życia w dążeniach do posiadania dóbr i używania życia. J. Pieter proponował ideał człowieka o prospołecznych postawach, kierującego się ściśle określonym systemem wartości. Według niego, człowiek uspołeczniony powinien przejawiać gotowość do solidarnej współpracy i mieć świadomość, że każde dzieło powstaje w wyniku współdziałania wielu osób. Wzajemna współpraca powinna się opierać na określonych normach, w których dominują odpowiedzialność i koleżeńska solidarność. W ten sposób zbudowane uspołecznienie powinno prowadzić do gotowości udzielania pomocy innym ze względu na prospołeczne postawy, a nie wyrachowanie czy oczekiwaną nagrodę. Jednostka w swoim życiu powinna się kierować z góry ustalonym systemem wartości, opartym na odpowiednim stosunku do dóbr kultury. Dobra materialne nie miały już przedstawiać największej wartości jako podstawowy środek zaspokajania własnych potrzeb. Jednostka uspołeczniona miała ograniczyć swoją niezależność osobistą na rzecz potrzeb innych osób lub interesu społecznego. Powinna jednocześnie zadbać o swoją odrębność umysłową i moralną, rozwijać własne zdolności twórcze, wykorzystując możliwości działania dla dobra własnego i innych. Naturalne skłonności do wytwarzania, będące powszechną cechą spotykaną u człowieka uspołecznionego, mają pozostać podstawowym źródłem zadowolenia, samorealizacji, rozładowania ambicji i porozumienia się z innymi ludźmi. Określone w ten sposób zadania wychowawcze powinny od najmłodszych lat kształtować w jednostce prospołeczne przyzwyczajenia i postawy ${ }^{12}$. O relacjach między moralnością a polityka wypowiadał się Tadeusz Wojeński. W swoim artykule zatytułowanym

10 S. G o de c ki, Szkolnictwo spółdzielcze, NS 1945, nr 6, s. 38-42.

11 S. G o d l e w s ki, W jakim kierunku powinno iść szkolnictwo handlowe?, NS 1946, nr 3, s. 25-33.

12 J. Pieter, Ideał wychowawczy nowej szkoły - człowiek uspołeczniony, NS 1945, nr 4-5, s. $1-17$. 
Wychowanie - moralność - polityka ${ }^{13}$ pisał, że błędne jest przekonanie, iż wychowanie obywatelskie można realizować w oderwaniu od istniejącej rzeczywistości. W jego odczuciu moralność i polityka to jedność. W związku z tym nic nie stoi na przeszkodzie, aby treści polityczne wprowadzać do każdej dziedziny życia szkolnego, w tym także do wychowania.

Jednym z niewielu głosów polemicznych w tym okresie jest artykuł dyskusyjny Andrzeja Baculewicza Szkolnictwo zawodowe w nowym ustroju szkolnym. Autor dostrzegał konieczność wprowadzenia zmian w tym szkolnictwie, ale nie za sprawą nowego ustroju szkolnego, tylko poprzez zaspokojenie doraźnych potrzeb płynących z gospodarki. Opowiadał się za przebudową szkół dokształcających i twierdził, że wszystko było w nich niewłaściwe: nazwa i założenia, organizacja, programy oraz efekty kształcenia. Według niego, dwustopniowe szkolnictwa zawodowe powinno mieć jako podbudowę ośmioklasową szkołę ogólnokształcącą, z założeniem, że jego drugi stopień będzie otwierał niczym nieograniczoną drogę do studiów wyższych. Proponował też powołanie gminnych i powiatowych szkół rolniczych oraz szkół fabrycznych w większych ośrodkach przemysłowych ${ }^{14}$.

Do wyraźnego ożywienia dyskusji nad dalszym ustrojem szkolnictwa na łamach czasopism pedagogicznych doszło bezpośrednio przed wprowadzeniem w 1948 r. jedenastoletniej szkoły ogólnokształcącej. Powzięte w sprawie szkolnictwa ogólnego kroki miały określony wpływ na szkolnictwo zawodowe. Już w 1947 r. w „Nowej Szkole” ukazał się artykuł S. Skrzeszewskiego pt. Nasza polityka oświatowa i Stanisława Kwiatkowskiego Drogi rozwoju szkolnictwa zawodowego w Polsce Ludowej. Pierwszy miał charakter czysto propagandowy, drugi natomiast prezentował osiągnięcia szkolnictwa zawodowego w latach 1945-1947, znaczenie podczas realizacji trzyletniego planu odbudowy państwa oraz rolę i miejsce nowej szkoły zawodowej w rodzącej się Polsce Ludowej. O zadaniach nowej szkoły informowało przemówienie S. Skrzeszewskiego, wygłoszone na naradzie aktywu oświaty PPR, które ukazało się w "Głosie Nauczycielskim”. Minister domagał się rozstrzygnięcia kwestii pełnej szkoły jedenastoletniej (o klasach I-XI) w kontekście pozostawienia dotychczasowej podbudowy szkoły podstawowej (klasy I-VII) dla szkoły średniej (klasy VIII-XI). Nie bez znaczenia było dla niego opowiedzenie się za takim systemem szkolnym, w którym uczeń mógłby przechodzić bez trudu ze szkoły podstawowej do średniej ogólnej oraz z zawodowej do wyższej ${ }^{15}$.

W 1948 r. na łamach „Ruchu Pedagogiczego” opublikowano głos Mariana Falskiego w obronie ośmioletniej szkoły powszechnej. Autor przypomniał lansowane wcześniej hasło ośmioletniej szkoły powszechnej o jednakowym poziomie kształcenia dla wszystkich i trzy- lub czteroletniej szkole ogólnokształcącej lub zawo-

${ }_{13}^{13}$ T. Woje ń s ki, Wychowanie - moralność - polityka, NS 1947, nr 1-2, s. 1-7.

${ }^{14}$ A. J. B a c u l e w i c z, Szkolnictwo zawodowe w nowym ustroju szkolnym (artykuł dyskusyjny), NS 1945 , nr 8, s. 23-35.

${ }^{15} \mathrm{~S}$. Skrzeszewski, Zadania szkoły na nowym etapie. Z przemówienia ministra dra St. Skrzeszewskiego na naradzie aktywu oświatowego PPR, „Głos Nauczycielski” [dalej: GN] 1948, nr 19, s. 310-311. 
dowej, stanowiącej jej dalszy etap. Dostrzegał konieczność rozwoju szkolnictwa zawodowego, opartego na dobrze zorganizowanej ośmioletniej szkoły powszechnej, które za sprawą nierównomiernego rozwoju gospodarczego i skomplikowanych stosunków międzynarodowych zostało znacznie zdecentralizowane. Według niego, o rozwój ten powinny zadbać zainteresowane ministerstwa, organizacje społeczne i zawodowe. Powinna nastąpić rozbudowa szkolnictwa zawodowego, uwzględniająca rzetelnie określone potrzeby życia gospodarczego i jego właściwe usytuowanie w całym ustroju szkolnym. Biorąc pod uwagę nie tylko doraźne, lecz także długofalowe cele, szkolnictwo musiało liczyć się z ewolucją życia gospodarczego, z postępem techniki i zmianą organizacji życia społecznego. W dotychczasowych formach kształcenia zawodowego M. Falski dostrzegał doraźne i mało zadowalające rozwiązania, które sprawiały, że ciągle obniżał się poziom tego szkolnictwa. W ostateczności opowiedział się przeciw łączeniu szkolnictwa powszechnego ze średnim w jednolite szkolnictwo ogólnokształcące, ponieważ rozwiązania takie mogły doprowadzić do pozostawienia szkolnictwa zawodowego na uboczu i drugim planie ${ }^{16}$.

Po 1948 r. wrócił temat świeckości szkoły. Domagano się oddzielenia Kościoła od państwa i wynikającej z tego konieczności wprowadzenia w Polsce Ludowej szkoły świeckiej. Nie obeszło się bez ataku na szkoły prywatne i prowadzone przez zgromadzenia zakonne. W prasie nauczycielskiej możemy w tym czasie spotkać wiele krytycznych uwag pod adresem dotychczasowej działalności ZNP i prezentowanej przez tę organizację linii ideowej. W tym nurcie mieści się wypowiedź Wacława Polkowskiego, zamieszczona w „Głosie Nauczycielskim”, z której wynika, że domagał się szkoły świeckiej i ostro krytykował przedwojenną działalność ZNP, nie szczędząc ostrych słów: „Droga, którą kroczył ZNP w latach 19261939 pełna była odchyleń i zygzaków. Związkiem kierowali naiwni ludzie, którzy szli razem z sanacją i popierali system faszystowski” i dalej: „Dopiero zwycięstwo demokracji ludowej w Polsce umożliwiło ZNP realizację postępowego programu oświatowego"17. Ocenę podsumowującą dotychczasową działalność związku nauczycielskiego możemy z pewnością zaliczyć do bardzo niesprawiedliwych. Nie bez znaczenia był fakt, że została wygłoszona w atmosferze dopiero co zakończonego Kongresu PZPR i mocnych słów wypowiedzianych pod adresem Związku przez Bolesława Bieruta, Józefa Cyrankiewicza i Aleksandra Zawackiego.

Niezwykle ożywioną dyskusję w omawianym okresie wywoływał problem kształcenia nauczycieli dla szkolnictwa zawodowego. Stanisław Wiśniewski w zamieszczonym w „Nowej Szkole” artykule proponował wykorzystanie dotychczasowych doświadczeń w tym zakresie i pozostanie przy istniejącym systemie przygotowania pedagogów. Wysoko oceniał zaproponowane przez Departament Szkolnictwa Zawodowego Ministerstwa Oświaty formy kształcenia nauczycieli, które w pełni zaspokajały obecne potrzeby szkolnictwa zawodowego. Dostrzegał jednocześnie ważną rolę szkół wyższych i ośrodków doskonalenia zawodowego,

${ }^{16}$ M. F alski, Uwagi w obronie 8-letniej szkoły powszechnej i w sprawie jej realizacji, „Ruch Pedagogiczny", marzec-maj 1947/1948, nr 3, s. 213-238.

17 W. P ol k o w s k i, O szkołę świecką, GN 1949, nr 1-2, s. 2. 
które mogłyby korzystnie wpłynąć na jakość przyszłego kształcenia nauczycieli szkół zawodowych ${ }^{18}$.

Nieco inaczej przebiegała dyskusja nad dalszym ustrojem szkolnictwa zawodowego w Polsce po przeprowadzeniu w 1948 r. reformy szkolnictwa ogólnokształcącego. W następnym roku powołano Centralny Urząd Szkolenia Zawodowego, który - jak się później okazało - dokonał zasadniczych zmian w ustroju szkolnictwa zawodowego. W miejsce przedwojennych szkół dokształcających, niższych szkół zawodowych, gimnazjów i liceów zawodowych oraz szkół przysposobienia zawodowego wprowadził szkoły przysposobienia zawodowego, zasadnicze szkoły zawodowe i technika zawodowe. O tym, jak przebiegała dyskusja nad nowym ustrojem szkolnictwa zawodowego mogą świadczyć artykuły z "Nowej Szkoły” i „Głosu Nauczycielskiego” autorstwa Władysława Ozgi, który był dyrektorem departamentu planowania w Ministerstwie Oświaty. Podkreślał w swoich tekstach, że po okresie poszukiwania nowych rozwiązań w pierwszych latach powojennych dopiero teraz przyszedł czas na właściwe reformy. Nie ukrywał też faktu, że opracowując je wzorowano się na radzieckich rozwiązaniach w zakresie organizacji szkolnictwa zawodowego. W szerokim uzasadnieniu starał się udowodnić ścisłe powiązania reformy szkolnictwa zawodowego z potrzebami przygotowanego planu 6-letniego. Zdawał sobie sprawę z tego, że uzyskanie pełnych kwalifikacji robotniczych i technicznych wymaga stosunkowo długiego czasu szkolenia, tymczasem potrzeby związane z realizacją tego planu wymuszały właściwie natychmiastowe przygotowanie młodej kadry, którą należało skierować do bieżącej produkcji. Założenia te można było osiągnąć dzięki wprowadzeniu krótkiego, kilkumiesięcznego przeszkolenia. Oczekiwaniom tego rodzaju mogły sprostać jedynie 6-miesięczne szkoły przysposobienia przemysłowego, do których starano się przyciągnąć młodzież poprzez zapewnienie jej bezpłatnej nauki (utrzymanie, mieszkanie, umundurowanie) ${ }^{19}$. Drugi artykuł W. Ozgi zatytułowany Perspektywy rozwoju oświaty w planie 6-letnim ukazał się w „Nowej Szkole” w numerze styczeń-kwiecień 1950 r. Był to bardzo obszerny, obejmujący 33 strony, tekst omawiający wewnętrzną i międzynarodową sytuację polityczną Polski oraz korzyści płynące z rozwoju i przebudowy gospodarczej kraju w duchu planu 6-letniego. Skierowano go głównie do nauczycieli w celu zapoznania ich z kierunkami rozwoju oświaty w okresie realizacji planu 6-letniego. Miał on być bardzo konkretnym materiałem poglądowym do wykorzystania na wszelkiego rodzaju kursach i konferencjach organizowanych dla nauczycieli. Przyjęto w nim sztywne zasady, zgodnie z którymi „realizacja planu 6-letniego ma stworzyć mocne podstawy dla rozwoju nowej kultury, kultury socjalistycznej”. Najogólniej rzecz ujmując, zadania planu 6-letniego w dziedzinie oświaty sprowadzono do: „likwidacji pozostawionego w spadku po rządach obszarniczo-kapitalistycznych Polski przedwrześniowego zacofania kulturalnego mas ludowych; pełnego udziału robotników i chłopów w tworzeniu kultury i korzystania $z$ dorobku kulturalnego narodu poprzez zapew-

18 S. W i ś n i e w s k i, Kształcenie nauczycieli szkół zawodowych, NS 1948, nr 1, s. 24-36.

19 W. Ozga, Nowy ustrój szkolnictwa zawodowego ujednolici system szkolenia, GN 1950, nr 37, s. 3. 
nienie masom ludowym dostatecznie wysokiego poziomu oświaty powszechnej; zmniejszenia dysproporcji kulturalnych między wsią a miastem; stworzenia nowej ludowej inteligencji”. Jednym z głównych zadań rodzącego się systemu miała być oświata i wychowanie, które w okresie planu 6-letniego będą w świadomości ludzkiej przezwyciężać przeżytki kapitalizmu i stworzą mocną konstrukcję pschiczną człowieka socjalizmu. Nie bez znaczenia była też konieczność przygotowania nowych kadr fachowych w ilości proporcjonalnej do wzrostu zatrudnienia oraz nasycenie gospodarki kadrami zgodnie ze stanem zapotrzebowania zalecanego przez literaturę fachową i naukową ${ }^{20}$.

Zaprezentowane powyżej dwa artykuły miały przygotować do lansowanej wówczas tezy, że szkolnictwo zawodowe powinno odgrywać ważną rolę w przebudowie ekonomicznej Polski, co stanowi wyraz troski rządu ludowego o nowe kadry dla rozbudowującego się przemysłu. Te i pozostałe artykuły z tego czasu miały towarzyszyć przeprowadzanym reformom i dalszym działaniom istniejącego od lipca 1949 r. Centralnego Urzędu Szkolenia Zawodowego. Miały wpłynąć dodatkowo na ugruntowanie pozycji tego organu powołanego do planowania i kierowania szkolnictwem zawodowym oraz instytucji przygotowującej kadry dla podstawowych gałęzi naszej gospodarki.

Z przeprowadzonej analizy czasopism pedagogicznych, które ukazywały się w latach 1945-1951 wynika, że na ich łamach dość często pisano o sprawach przyszłego ustroju szkolnictwa zawodowego w Polsce. Wypowiedzi omawiające wspomnianą problematykę starano się zamieszczać właściwie we wszystkich czasopismach o charakterze pedagogicznym. Wybrane do analizy artykuły publikowane w „Głosie Nauczycielskim”, „Nowej Szkole”, „Ruchu Pedagogicznym” i „Szkole Zawodowej” wydają się najbardziej odpowiednie jako ilustracja dyskusji o przyszłym ustroju szkolnictwa zawodowego. Wymienione czasopisma odegrały największą rolę w procesie kształtowania opinii ówczesnego środowiska nauczycielskiego, budziły duże zainteresowanie elit politycznych i związkowych. „Głos Nauczycielski" pozostawał centralnym organem Związku Nauczycielstwa Polskiego. „Nowa Szkoła” była wydawana przez organ państwowy Ośrodka Oświatowych Prac Programowych i Badań Pedagogicznych oraz Wydział Społeczno-Pedagogiczny Związku Nauczycielstwa Polskiego. Podobnie „Ruch Pedagogiczny” i „Szkoła Zawodowa”.

Wymienione czasopisma w jakimś sensie odgrywały też rolę propagandową. Bardzo często w omawianym okresie pojawiały się w nich przedruki przemówień politycznych, ważniejsze wypowiedzi z zebrań partyjnych i spotkań związkowych oraz wystąpienia na zjazdach oświatowych. Sprawy oświaty zaprezentowano na VII sesji KRN w przemówieniu premiera rządu E. Osóbki-Morawskiego. Prawie w całości drukowane były np. przemówienia ministra S. Skrzeszewskiego i C. Wycecha ze Zjazdu Walnego ZNP w Bytomiu w 1945 r. ${ }^{21}$ W całości lub większych fragmentach publikowano przemówienia B. Bieruta, J. Cyrankiewicza oraz innych

20 W. O z g a, Perspektywy rozwoju oświaty w planie 6-letnim, NS 1950, nr 1-2, s. 3-33.

${ }^{21}$ Przemówienie Ministra Wycecha na Zjeździe Walnym ZNP w Bytomiu, NS 1945, nr 8, s. 76-83. 
dysydentów partyjnych i związkowych. W 1946 r. zamieszczono w „Głosie Nauczycielskim" skrócony referat K. Maja ze Zjazdu Delegatów w Bytomiu pt. Podstawy ideologiczne polityki oświatowej22 i dość ostrą jego odpowiedź na dyskusję o wyborze drogi do demokracji23.

Odważniejsze wypowiedzi środowiska nauczycielskiego i krótkie artykuły polemiczne na temat ustroju szkolnictwa zawodowego spotkać można w nieomawianej tutaj prasie codziennej, zarówno o zasięgu krajowym, jak i lokalnym. Prasa codzienna szybciej docierała do ogółu społeczeństwa i wydawała się lepszym miejscem do prezentacji wszelkiego rodzaju poglądów i polemik. W pełni mogła być wykorzystana do celów propagandowych. Zawarte w gazetach artykuły, fragmenty referatów i wystąpienia zjazdowe oraz aktualności i kroniki wydarzeń stanowić mogą również nieocenione źródło do badań nad szeroko pojmowanymi dziejami szkolnictwa zawodowego w Polsce.

22 K. M a j, Podstawy ideologiczne polityki oświatowej, GN 1946, nr 1, s. 3-9.

${ }^{23}$ K. M a j, Droga do demokracji, GN 1946, nr 3, s. 35. 